\title{
Pengaruh Media Video Edukasi terhadap Peningkatan Pengetahuan Anemia pada Remaja Putri
}

\author{
The Effect of Educational Video Media on Increasing Knowledge \\ of Anemia in Adolescent Girl
}

\author{
${ }^{1 *}$ Tri Marta Fadhilah, ${ }^{2)}$ Ferar Zidni Qinthara, ${ }^{3)}$ Faiz Pramudiya, ${ }^{4)}$ Firdha Safinah Nurrohmah, \\ ${ }^{5}$ Haliza Putri Nurlaelani, ${ }^{6}$ Nita Maylina, ${ }^{7}$ Nuke Alfiraizy \\ ${ }_{1,2,3,4,5,6,7)}$ Program Studi S1 Gizi STIKes Mitra Keluarga \\ Jl. Pengasinan Jl. Rw. Semut Raya, Margahayu, \\ Kec. Bekasi Tim., Kota Bks, Jawa Barat 17113 \\ *email: trimartafadhilah15@gmail.com
}

DOI:

10.30595/jppm.v5i1.9823

Histori Artikel:

Diajukan:

13/02/2021

Diterima:

$11 / 01 / 2022$

Diterbitkan:

18/02/2022

\section{ABSTRAK}

Remaja yaitu penduduk yang masih tergolong dalam rentan usia 10-19 tahun. Anemia adalah suatu keadaan dimana kadar hemoglobin (Hb) dalam darah kurang dari normal. Keadaan social ekonomi rendah seperti Pendidikan orang tua dan penghasilan yang rendahserta Kesehatan lingkungan yang buruk merupakan factor yang mempengaruhi tingginya prevalensi anemia gizi besi di Inodesia. Pemberian edukasi pendidikan gizi ini dilakukan secara online pada bulan Desember 2020. Sasaran kegiatan edukasi pendidikan gizi ini adalah Remaja Putri dengan membagikan media berupa video edukasi yang berisi beberapa cuplikan dengan instrumen powtoon. Metode yang digunakan dalam penyuluhan ini yaitu menggunakan metode video terkait anemia dengan instrumen powtoon dan kuesioner. Kegiatan pemberian edukasi gizi ini diawali dengan penyebaran flyer yang mencantumkan link kuesioner pre-test (Sebelum menonton video) dan link kuesioner post-test (Setelah menonton video). Pendidikan edukasi gizi ini bertujuan untuk meningkatkan pengetahuan remaja putri terkait Anemia dan pentingnya mencegah Anemia. Hasil data umur responden paling banyak pada kelompok Remaja Akhir (Usia 18 - 21 tahun) yaitu 47 orang (61\%). Sedangkan data asal provinsi lebih banyak pada Jawa barat yaitu 48 orang (62\%). Hasil dari perhitungan statistika, data pengetahuan Anemia terhadap remaja putri menunjukan peningkatan yang signifikan dengan nilai p-value <0,05. Kesimpulan kegiatan ini adalah terdapat pengaruh peningkatan antara sebelum dan setelah diberikan pendidikan gizi melalui video pengetahuan anemia pada remaja putri.

Kata kunci: Media Video Edukasi; Pengetahuan Anemia; Remaja Putri

\begin{abstract}
Adolescents are people who are still classified as vulnerable aged 10-19 years. Anemia is a condition in which the hemoglobin $(\mathrm{Hb})$ level in the blood is less than normal. Low socioeconomic conditions such as parental education and low income and poor environmental health are factors that influence the high prevalence of iron deficiency anemia in Inodesia. The provision of nutrition education education was carried out online in December 2020. The target of this nutrition education education activity is Young Women by distributing media in the form of educational videos containing several snippets with powtoon instruments. The method used in this counseling is using the video method related to anemia with the powtoon instrument and a questionnaire. This nutrition education activity begins with distributing flyers that include the pre-test questionnaire link (before watching the video) and the post-test questionnaire link (after watching the video). This nutrition education
\end{abstract}


Tri Marta Fadhilah, Ferar Zidni Qinthara, Faiz Pramudiya, Firdha Safinah Nurrohmah, Haliza Putri Nurlaelani, Nita Maylina, Nuke Alfiraizy

Pengaruh Media Video Edukasi terhadap Peningkatan Pengetahuan Anemia pada Remaja Putri

education aims to increase the knowledge of young women regarding anemia and the importance of preventing anemia. The results of data on the age of the most respondents were in the Late Adolescence group (ages 18-21 years), namely 47 people (61\%). Meanwhile, data from provinces is mostly in West Java, namely 48 people (62\%). The results of statistical calculations, data on anemia knowledge of adolescent girls showed a significant increase with a p-value $<0.05$. The result of this activity was that there was an effect between before and after being given nutrition education through videos of knowledge of anemia in adolescent girls.

Keywords: Educational Media Video; Knowledge of Anemia; Teenage Girl

\section{PENDAHULUAN}

Remaja (adolescence) adalah masa peralihan dari anak-anak menuju dewasa, dimana individu berkembang dari saat pertama kali ia menunjukkan tanda-tanda seksual sekundernya (pubertas) sampai saat ia mencapai kematangan seksual. Remaja yaitu penduduk yang masih tergolong dalam rentan usia 10-19 tahun (WHO, 2010). Adapun remaja menurut Badan Kependudukan dan Keluarga Berencana Nasional (BKKBN) yaitu mereka yang digolongkan dalam usia 10-24 tahun dan masih berstatus belum menikah.

Pada usia remaja terjadi perubahan pada fisik, biologis, dan psikologis seseorang dan terjadi secara terus-menerus selama usia remaja. Ketidakseimbangan antara asupan dan kebutuhan gizi berakibat pada terjadinya masalah gizi (Briawan, 2013).Masalah gizi yang terjadi pada usia remaja merupakan efek kelanjutan dari masalah gizi yang terjadi saat masih anak-anak. Masalah tersebut antara lain anemia defisiensi besi, kekurangan dan kelebihan berat badan. Kebiasaan makan yang dilakukan semasa remaja akan memberikan dampak terhadap kondisi kesehatan pada fase kehidupan selanjutnya (Sya'bani \& Sumarmi, 2016).

Kekurangan asupan zat besi dapat menyebabkan anemia. Anemia merupakan masalah gizi yang paling umum di seluruh dunia, terutama disebabkan karena defisiensi besi (WHO, 2010). Anemia merupakan suatu keadaan di mana ada penurunan hemoglobin (pemberi warna merah dan pengakut oksigen darah) per unit volume darah di bawah kadar normal yang sudah di tentukan untuk usia dan jenis kelamin tertentu. Ketentuan WHO mengenai anemia ialah $12 \mathrm{mg} \mathrm{Hb} / \mathrm{dl}$ darah bagi perempuan dan di bawah $14 \mathrm{mg} \mathrm{Hb} / \mathrm{dl}$ darah untuk laki-laki dan hematokrit di bawah
34\% (Merryana, 2012).Gejala klinis anemia dapat berupa lesu, lemah, pusing, mata berkunang-kunang dan wajah pucat (Adriani, 2012).

Kekurangan zat besi tidak terbatas pada remaja dengan status sosial pedesaan yang rendah, tetapi juga menunjukan peningkatan prevalensi di masyarakat makmur dan berkembang (Suryani, 2015). Remaja putri mempunyai resiko mengalami Anemia lebih tinggi daripada remaja laki-laki karena setiap bulannya remaja putri mengalami menstruasi. Menurut World Health Organization (WHO), prevalensi anemia dunia berkisar $40-88 \%$. Angka kejadian anemia pada remaja putri di negara berkembang sekitar $53,7 \%$ dari semua remaja putri (WHO, 2010).

Secara garis besar, sebanyak $44 \%$ wanita di negara berkembang 10 negara di Asia Tenggara, termasuk Indonesia mengalami anemia kekurangan besi. Berdasarkan hasil Riskesdas (2013), prevalensi anemia di Indonesia yaitu $21,7 \%$ dengan penderita anemia berumur 5-14 tahun sebesar 26,4\% dan $18,4 \%$ penderita berumur 15-24 tahun. Data Survei Kesehatan Rumah Tangga (SKRT) tahun 2012 menyatakan bahwa prevalensi anemia pada remaja putri usia 10-18 tahun sebesar 57,1\% dan usia 19-45 tahun sebesar $39,5 \%$. Kemudian berdasarkan penelitian Burner (2012) angka prevalensi anemia di Indonesia pada remaja putri sebesar $26,50 \%$. Sedangkan, prevalensi anemia yang terjadi di Provinsi Jawa Barat sebesar 51,7\% (Depkes, 2012). Kemudian berdasarkan penelitian Lina Fitriani (2015) menyatakan bahwa prevalensi anemia di Bekasi sebesar 44,6\%.

Faktor-faktor pendorong anemia pada remaja putri adalah adanya penyakit infeksi, menstruasi yang berlebihan pada remaja putri, 
perdarahan yang mendadak seperti kecelakaan,jumlah makanan atau penyerapan diet yang buruk,penyakit cacingan pada remaja, tingkat pendidikan orang tua, tingkat ekonomi, tingkat pengetahuan tentang anemia dari remaja putri (Merryana, 2012). Dampak anemia yang dialami remaja putri akan membuat remaja merasa lesu, bisa menurunkan kemampuan daya ingat sehingga prestasi akademik tidak optimal dan juga dapat berdampak lebih serius, mengingat mereka adalah para calon ibu yang akan hamil dan melahirkan bayi, sehingga memperbesar risiko kematian ibu, melahirkan bayi premature dan berat bayi lahir rendah (Briawan, 2013).

Pengetahuan yang kurang merupakan salah satu faktor pendorong terjadinya anemia pada remaja. Oleh karena itu, kami ingin melakukan upaya bersifat preventif yaitu dengan cara pemberian edukasi gizi terkait anemia khususnya pada remaja putri dengan menggunakan media video guna untuk meningkatkan kesadaran pada remaja akan pentingnya mencegah terjadinya Anemia.

Pendidikan edukasi gizi ini bertujuan untuk meningkatkan pengetahuan remaja terkait Anemia dan pentingnya mencegah terjadinya Anemia.

\section{METODE}

Pemberian edukasi pendidikan gizi ini dilakukan secara online pada bulan Desember 2020. Edukasi pendidikan gizi yang dilakukan bertemakan "Anemia pada Remaja" dengan membagikan media berupa video edukasi yang berisi beberapa cuplikan dengan instrumen powtoon. Metode yang digunakan dalam penyuluhan ini yaitu menggunakan metode video terkait anemia dengan instrumen powtoon dan kuesioner.

Survei dilakukan dengan cara melakukan 2 kuisioner yaitu pre-test dan posttest untuk mengetahui pengetahuan dan perilaku pada remaja tentang gejala anemia sesaat sebelum dan sesudah menonton video edukasi gizi. Materi kegiatan edukasi gizi dengan tema Pengetahuan Anemia Pada Remaja Putri adalah sebagai berikut, terdiri atas materi dan 2 sesi kuisioner (Pre-test dan
Post-test). Ketiga materi yang dimaksud terdiri dari, pengetahuan tentang pengertian anemia, gejala anemia, faktor anemia, menanggulangi anemia, cara mengatasi anemia pada remaja ketika menstruasi, pentingnya zat besi untuk anemia, bahan pangan yang mengandung zat besi, bahan pangan yang membantu dalam proses penyerapan dan menghambat penyerapan zat besi.

Sasaran pada kegiatan edukasi ini adalah remaja putri diperkotaan dan diperdesaan dengan total responden 77 remaja putri. Berdasarkan hasil survey dan obervasi ditentukan yaitu remaja diperkotaan dan remaja diperdesaan. Kegiatan ini akan dilakukan pada bulan Oktober 2020 sampai dengan bulan Januari 2021.

\section{HASIL DAN PEMBAHASAN}

Kegiatan edukasi gizi ini dilakukan secara online dengan cara penyebaran link video yang bertemakan "Anemia Pada Remaja Putri” yang di tujukan kepada para remaja putri. Dengan pengisian kuesioner sebelum dan sesudah menonton video edukasi gizi.

Kegiatan pemberian edukasi gizi ini diawali dengan penyebaran flyer yang mencantumkan link kuesioner pre-test (Sebelum menonton video) dan link kuesioner post-test (Setelah menonton video). Kuesioner pre-test dapat diakses dengan link: https://bit.ly/Anemiapretest berisikan surat persetujuan ketersediaan menjadi responden, kemudian responden menjawab benar atau salah pada pernyataan - pernyataan yang tersedia di dalam kuesioner. Berikut gambar kuesioner online menggunakan google form. 
Tri Marta Fadhilah, Ferar Zidni Qinthara, Faiz Pramudiya, Firdha Safinah Nurrohmah, Haliza Putri Nurlaelani, Nita Maylina, Nuke Alfiraizy

Pengaruh Media Video Edukasi terhadap Peningkatan Pengetahuan Anemia pada Remaja Putri

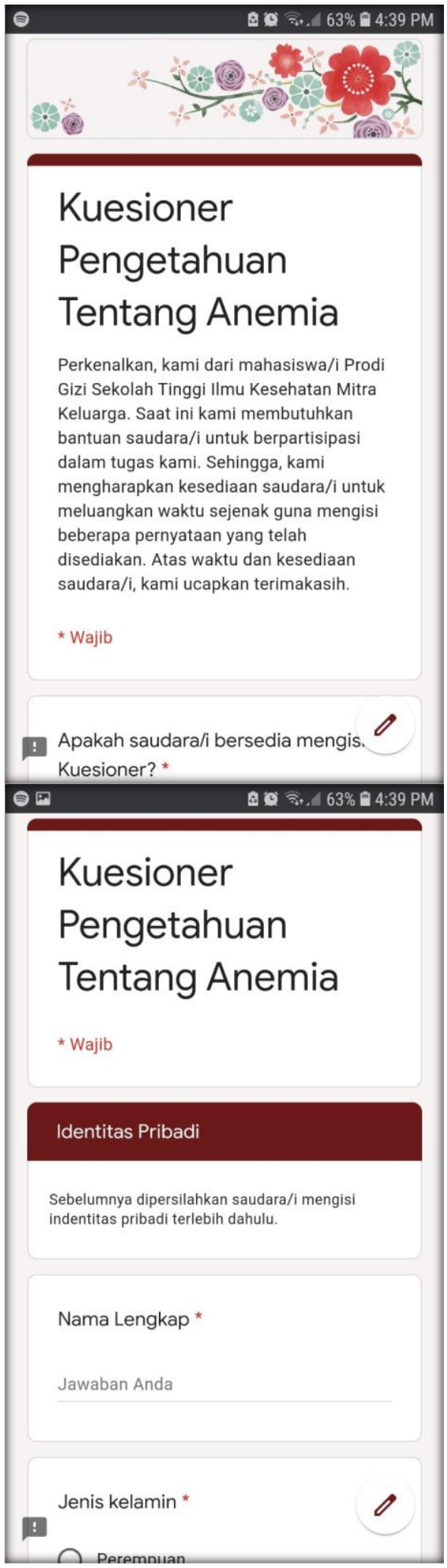

gizi tersebut, di akhir video kami mengingatkan responden untuk kembali mengisi kuesioner post-test yang dimana link nya https://bit.ly/Anemiapostest kami cantumkan pada description box. Berikut gambar peserta yang sedang melihat video pada link youtube.

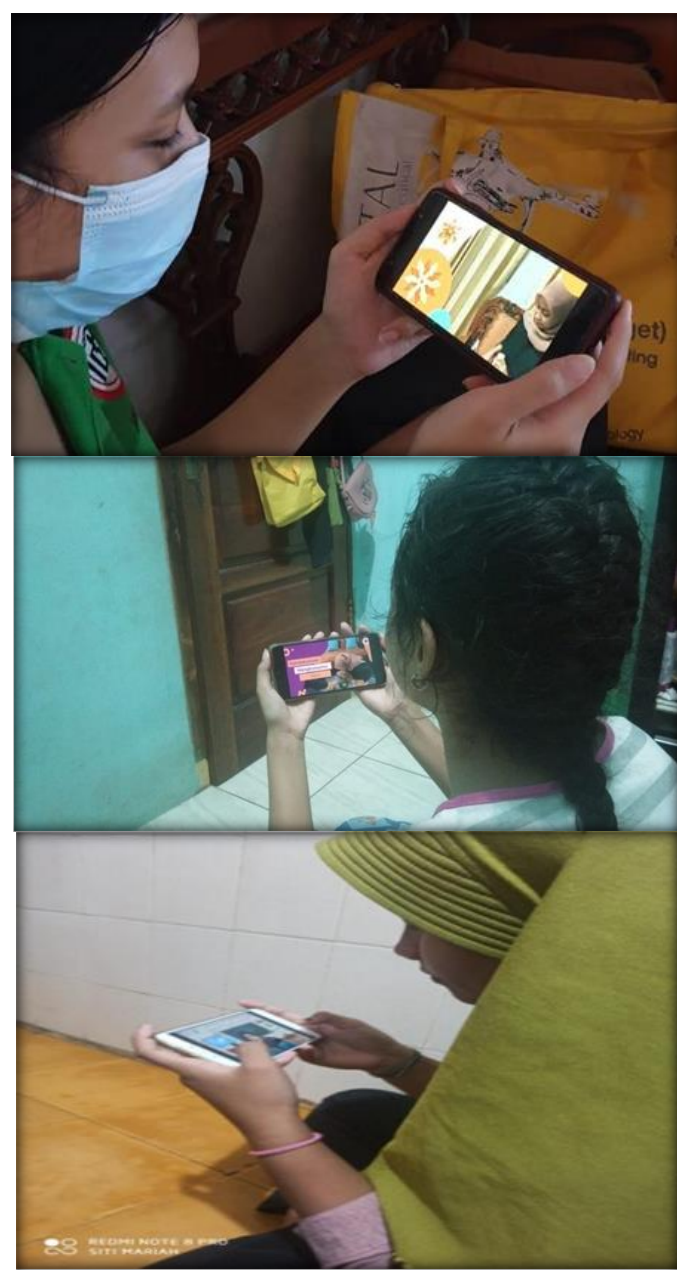

Kegiatan edukasi ini karateristik responden yang diambil adalah usia remaja dan tempat tinggal, yang dapat dilihat pada tabel 1 .

Dalam kuesioner pre-test juga terdapat link video: https://youtu.be/BCKxL1NoRYA. Setelah responden menonton video edukasi 
Tri Marta Fadhilah, Ferar Zidni Qinthara, Faiz Pramudiya, Firdha Safinah Nurrohmah, Haliza Putri Nurlaelani, Nita Maylina, Nuke Alfiraizy

Pengaruh Media Video Edukasi terhadap Peningkatan Pengetahuan Anemia pada Remaja Putri

Tabel 1. Umur, dan Provinsi Subjek Penelitian

\begin{tabular}{llcc}
\hline & Karakteristik & \multicolumn{2}{c}{ Responden } \\
& & N & $(\mathbf{\%})$ \\
\hline $\begin{array}{l}\text { Usia } \\
\text { (WHO, }\end{array}$ & 10-14 Tahun & 8 & 10 \\
(Remaja awal) & & \\
& & & \\
& & & \\
& 15 - 17 Tahun & 22 & 29 \\
& (Remaja & & \\
& Tengah) & & \\
& 18 - 21 Tahun & 47 & 61 \\
& (Remaja Akhir) & & \\
& DKI Jakarta & 7 & 10 \\
Provinsi & Jawa Barat & 48 & 62 \\
& Jawa Tengah & 20 & 26 \\
& DIY & 1 & 1 \\
& SulawesiSelatan & 1 & 1 \\
\hline Total Responden & $\mathbf{7 7}$ & $\mathbf{1 0 0}$ \\
\hline
\end{tabular}

Hasil data karakteristik responden pada kelompok pre-test dan post-test didapatkan semua responden berjenis kelamin perempuan sebanyak 77 orang $(100 \%)$. Data umur responden paling banyak pada kelompok Remaja Akhir (Usia 18 - 21 tahun) yaitu 47 orang $(61 \%)$. Sedangkan data asal provinsi lebih banyak pada Jawa barat yaitu 48 orang $(62 \%)$.

Pengetahuan tentang Anemia sangat dibutuhkan oleh para remaja putri untuk mencegah terjadinya gejala-gejala yang dapat mempengaruhi prestasi dalam belajar, yang dapat dilihat pada tabel 2 .

Tabel 2. Hasil perhitungan statistic pre-test dan post-test

\begin{tabular}{ccc}
\hline $\begin{array}{c}\text { Kuesioner } \\
\text { Anemia Remaja }\end{array}$ & \multicolumn{2}{c}{ Pengetahuan Remaja } \\
Mean \pm SD & p-value \\
\hline Pre-Test & $2,418 \pm 3,04$ & \\
Post-Test & $2,055 \pm 2,583$ & 0,000 \\
& &
\end{tabular}

Hasil dari perhitungan statistik data pengetahuan tentang Anemia pada para remaja putri menunjukan bahwa pada pre-test dan post-test mengalami kenaikan yang signifikan dengan nilai $<0,05$. Rata-rata kenaikan pengetahuan tentang Anemia dapat dilihat pada gambar di bawah ini:

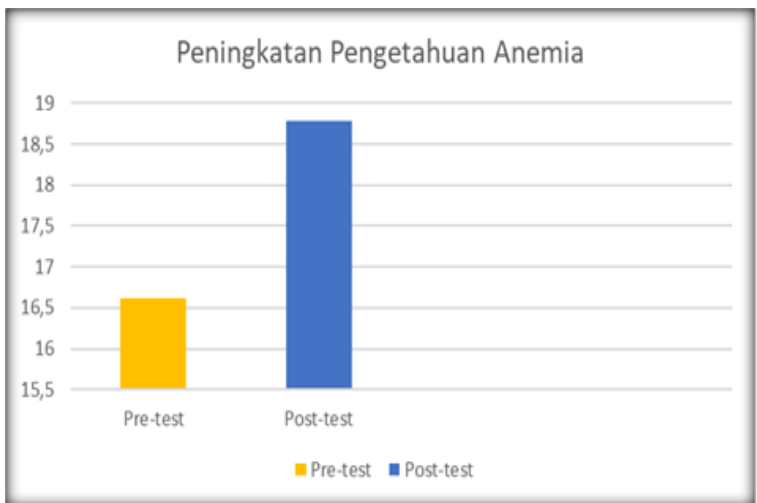

Gambar 1. Grafik Peningkatan Nilai Rata-rata pretest dan post-test

Di dapatkan hasil nilai rata-rata pretest yaitu 16,6 dan nilai rata-rata saat post-test yaitu 18,8. Hal ini dapat dikatakan bahwa Adanya peningkatan pengetahuan para remaja putri terkait Anemia saat sesudah dilakukannya edukasi gizi dibanding sebelum mendapatkan edukasi gizi, hal tersebut dapat dilihat dari hasil rata-rata nilaipre-test dan post-test yang mengalami kenaikan.

Remaja (adolescence) adalah masa peralihan dari anak-anak menuju dewasa, dimana individu berkembang dari saat pertama kali ia menunjukkan tanda-tanda seksual sekundernya (pubertas) sampai saat ia mencapai kematangan seksual. Remaja yaitu penduduk yang masih tergolong dalam rentan usia 10-19 tahun. Adapun remaja menurut Badan Kependudukan dan Keluarga Berencana Nasional (BKKBN) yaitu mereka yang digolongkan dalam usia 10-24 tahun dan masih berstatus belum menikah. Pada usia remaja terjadi perubahan pada fisik, biologis, dan psikologis seseorang dan terjadi secara terus-menerus selama usia remaja. Ketidakseimbangan antara asupan dan kebutuhan gizi berakibat pada terjadinya masalah gizi (Briawan, 2013). Masalah gizi yang terjadi pada usia remaja merupakan efek kelanjutan dari masalah gizi yang terjadi saat masih anak-anak. Masalah tersebut antara lain anemia defisiensi besi, kekurangan dan kelebihan berat badan. Kebiasaan makan yang dilakukan semasa remaja akan memberikan dampak terhadap kondisi kesehatan pada fase kehidupan selanjutnya (Sya'bani \& Sumarmi, 2016). 
Pada saat melakukan edukasi tersebut hasil yang kami peroleh berdasarkan usia karateristik responden berdasarkan usia menunjukan bahwa responden lebih banyak berusia 18 - 21 Tahun yang di mana kategori umur tersebut termasuk ke dalam fase remaja akhir sedangkan kareteristik responden berdasarkan usia lebih sedikit berusia $10-14$ Tahun yang di mana kategori umur tersebut termasuk kedalam fase remaja awal. Dari hasil yang kami peroleh bahwa kategori responden usia Remaja Akhir sangat antusias untuk mengikuti edukasi yang sudah kami berikan, namun untuk kategori responden usia Remaja Awal begitu kurang antusias dalam mengikuti edukasi pendidikan gizi yang sudah kami sampaikan.

Kekurangan zat besi tidak terbatas pada remaja dengan status sosial pedesaan yang rendah, tetapi juga menunjukan peningkatan prevalensi di masyarakat makmur dan berkembang (Suryani, 2015). Menurut Survei Kesehatan Rumah Tangga (SKRT) pada tahun 2012 menyatakan bahwa prevalensi anemia pada remaja putri Jawa Barat memiliki angka kejadian anemia sebesar $51,7 \%$ (Dieniyah et al., 2019). Remaja putri mempunyai resiko mengalami Anemia lebih tinggi daripada remaja laki-laki karena setiap bulannya remaja putri mengalami menstruasi. Menurut World Health Organization (WHO), prevalensi anemia dunia berkisar 40-88\%. Angka kejadian anemia pada remaja putri di negara berkembang sekitar $53,7 \%$ dari semua remaja putri (WHO, 2010).

Pada saat melakukan edukasi tersebut hasil yang kami peroleh berdasarkan karateristik responden provinsi tempat tinggal menunjukan bahwa responden lebih banyak di bandingkan pada daerah provinsi jawa tengah. Karena didapatkan dari provinsi Jawa barat yaitu 48 orang dengan persentase $62 \%$. Hal tersebut terjadi karena untuk daerah luar provinsi Jawa barat kami terkendala dalam penyebaran flyer.

\section{SIMPULAN}

Berdasarkan penjelasan diatas, maka dapat ditarik kesimpulan bahwa kegiatan edukasi ini berhasil dilakukan dengan membawa efek positif pada remaja putri terkait pengetahuan anemia dan pentingnya pencegahan anemia. Total peserta 77 remaja putri memberikan apresiasi yang baik meskipun kegiatan edukasi dilakukan secara online. Antusiasme pada remaja putri terlihat dari banyaknya pertanyaan dan komentar dari para remaja putri. Kesadaran para remaja putri dapat terlihat dari peningkatan pengetahuan setelah melihat video edukasi pada youtube. Selain itu remaja putri lebih mengetahui mencegahan dan penanggulangan masalah anemia pada dirinya masing-masing.

\section{DAFTAR PUSTAKA}

Adriani, M. \& Wirjatmadi, B. Peranan Gizi Dalam Siklus Kehidupan. Prenadamedia Group. Rawamangun; 2012.

Arisman. Gizi Dalam Daur Kehidupan. Jakarta: EGC; 2010.

Bachtiar, Muhammad Yusuf. 2015. Perbedaan Pengetahuan Pada Pendidikan Kesehatan Metode Ceramah dan Media Leaflet dengan Metode Ceramah dan Media Video tentang Bahaya Merokok Di SMK Kasatrian Solo. Naskah Publikasi. Universitas muhammdiyah Surakarta

Bakta IM, 2006, Pendekatan Terhadap Pasien Anemia. In: Sudoyo AW, Bambang Setiyohadi, Idrus Alwi, Marcellus Simadibrata K, Siti Setiati, editors, Buku Ajar Ilmu Penyakit Dalam, edisi IV, jilid II, Pusat Penerbitan Ilmu Penyakit Dalam FK UI. Jakarta. p.622-623

BKKBN. 2010. Remaja Genre dan Perkawinan Dini. Tersedia di: http://www.bkkbn.go.id/

Briawan, D. (2013). Anemia masalah gizi pada remaja wanita. Jakarta: EGC.

Dieniyah, P., Sari, M. M., \& Avianti, I. (2019). Hubungan Tingkat Pengetahuan Tentang Anemia Dengan Kejadian Anemia Pada Remaja Putri Di Smk Analisis Kimia Nusa Bangsa Kota Bogor Tahun 2018. Promotor, 151. https://doi.org/10.32832/pro.v2i2.1801 
Jaelani, M., Simanjuntak, B. Y., \& Yuliantini, E. (2017). Faktor Risiko yang Berhubungan dengan Kejadian Anemia pada Remaja Putri. Jurnal Kesehatan, $8(3)$, 358. https://doi.org/10.26630/jk.v8i3.625

Martini. (2015). Faktor-Faktor Yang Berhubungan Dengan Kejadian Anemia Pada Remaja Putri Di MAN 1 METRO. Jurnal Kesehatan Metro Sai Mawai Vol. 8(1) Edisi Juni 2015.

Masrizal. 2007. Anemia Defisiensi Besi. Jurnal Kesehatan Masyarakat, September 2007, II (1).

Merryana jp. 2012. Anemia pada Remaja Putri. Dikutip dari http://monikajp.blogspot.com/2012/12/an emia- pada-remaja-putri.html diakses tanggal 20 desember 2016.

Mularsih, S. (2017). Hubungan Pengetahuan Remaja Putri Tentang Anemia Dengan Perilaku Pencegahan Anemia Pada Saat Menstruasi Di Smk Nusa Bhakti Kota Semarang. Jurnal Kebidanan, 6(2), 80. https://doi.org/10.26714/jk.6.2.2017.8085

Nizmah, Nuniek, dkk. (2016). Gambaran Tingkat Pengetahuan Tentang Anemia Pada Remaja Putri (Public Health Problem). Jurnal Ilmu Kesehatan (JIK), IX(1), 1-6. ISSN 1978-3167

Priyanto, Lukman Dwi. 2018. Hubungan Umur, Tingkat Pendidikan, dan Aktivitas Fisik Santriwati Husada dengan Anemia. Jurnal Berkala Epidemiologi Volume 6 Nomor 2 (2018) 139-146.

RISKESDAS. Riset Kesehatan Dasar. 2013. Jakarta: Badan Penelitian dan Pengembangan Kesehatan, Depkes RI.

Sari, Hesti Permata, dkk. 2016. Anemia Gizi Besi Pada Remaja Putri Di Wilayah Kabupaten Banyumas. Jurnal Kesmas Indonesia, Volume 8 No 1, Januari 2016, Hal 16-31.

Suryani, D., Hafiani, R., \& Junita, R. (2015). Analisis pola makan dan anemia gizi besi pada remaja putri Kota Bengkulu. Jurnal Kesehatan Masyarakat Andalas, 10(1), 11-18.

Sari, P., Bestari, A. D., Pertiwi, W., \& Judistiani, T. D. (2019). Peningkatan Pengetahuan Remaja Putri Mengenai Anemia Defisiensi Besi Dan Pencegahannya Di Kecamatan Jatinangor. Dharmakarya, 8(4), 265-267. https://doi.org/10.24198/dharmakarya.v8i 4.21021

Silalahio, Veronica. 2016. Potensi Pendidikan Gizi Dalam Meningkatkan Asupan Gizi Pada Remaja Putri Yang Anemia di Kota Medan. Jurnal Kesehatan Masyarakat. Universitas Negeri Semarang.

Spear, Bonnie A, 2000, Adolescent Nutritions : General. In :Nutrition Throughout the Life Cycle.

Suraoka \& Supariasa .2012. Media Pendidikan Kese-hatan.Yogyakarta : Graha Ilmu

Sya'bani, I. R. N., \& Sumarmi, S. (2016). Hubungan status gizi dengan kejadian anemia pada santriwati di Pondok Pesantren Darul Ulum Peterongan Jombang. Jurnal Keperawatan Muhammadiyah, 1(1), 7-15.

Webster-Gandy, Joan. Angela Madden. Michelle Holdsworth, 2012. Oxford Handbook of Nutrition and Dietetics. Oxford public press. English 